\title{
Erratum to pembrolizumab-induced myocarditis in a patient with malignant mesothelioma: plasma exchange as a successful emerging therapy-case report
}

\author{
Editorial Office \\ Translational Lung Cancer Research \\ Correspondence to: Editorial Office. Translational Lung Cancer Research. Email: editor@tlcr.org.
}

doi: $10.21037 /$ tlcr-2021-3

View this article at: http://dx.doi.org/10.21037/tlcr-2021-3

Erratum to: Transl Lung Cancer Res 2021;10:1039-46

In the February 2021 issue of Translational Lung Cancer Research (TLCR), the case report "Pembrolizumab-induced myocarditis in a patient with malignant mesothelioma: plasma exchange as a successful emerging therapy-case report" (1) was published with one error. The author Sanziana R. I. Schiopu had a third affiliation which should be added as below.

3. First Department of Internal Medicine, "luliu Hatieganu” University of Medicine and Pharmacy, Cluj-Napoca, Romania

Click here to view the updated version of the article.

Open Access Statement: This is an Open Access article distributed in accordance with the Creative Commons AttributionNonCommercial-NoDerivs 4.0 International License (CC BY-NC-ND 4.0), which permits the non-commercial replication and distribution of the article with the strict proviso that no changes or edits are made and the original work is properly cited (including links to both the formal publication through the relevant DOI and the license). See: https://creativecommons.org/licenses/by-nc$\mathrm{nd} / 4.0 \%$.

\section{References}

1. Schiopu SRI, Käsmann L, Schönermarck U, et al. Pembrolizumab-induced myocarditis in a patient with malignant mesothelioma: plasma exchange as a successful emerging therapy—case report. Transl Lung Cancer Res 2021;10:1039-46.

Cite this article as: Editorial Office. Erratum to pembrolizumabinduced myocarditis in a patient with malignant mesothelioma: plasma exchange as a successful emerging therapy-case report. Transl Lung Cancer Res 2021;10(6):3029. doi: 10.21037/tlcr2021-3 